\title{
INVESTIGATING THE ANAHITA MYTH IN ANCIENT IRAN AND ARMENIA
}

\author{
Shohreh Javadi \\ Department of Science and History of Art, NAZAR Research Center, Tehran, Iran \\ \& Department of Art, University of Tehran, Tehran, Iran \\ Ali Nikoei \\ Department of Science and History of Art, NAZAR Research Center, Tehran, Iran \\ *Corresponding Author: ali.nikoei1981@gmail.com
}

\begin{abstract}
Iran and Armenia have had extensive historical, political and cultural relations over many millennia. Armenia was influenced by the Persian Empire from the Median era. This influence took place in both political as well as cultural and religious views. Iranians' religious influence on Armenians, happened by Gregory the Illuminator until Armenia became Christian in mid three century. Because Iranians and Armenians are of the same race and the two countries are close to each other, it seems that these two nations have had mutual effects on each other in various areas including religion and beliefs. Therefore, in this research, we try to investigate the position of lady Anahita among Iranians and Armenians in ancient times as well as the roots of the Iranian goddess' influence on the Armenian deity.
\end{abstract}

Keywords: Anahita, Iran, Armenia, Achaemenian Artaxerxes II

\section{HYPOTHESIS}

In ancient times, Iranians' religious beliefs affected Armenians' beliefs very much. For example, the Iranian goddess "Anahita" who influenced the Armenian "Nane" and the Iranian Anahita turned into "Anahit" who took the characteristics of the Iranian deity.

\section{INTRODUCTION}

Anahita is a goddess described with special adjectives. In Yashts, she is described as being powerful, white, beautiful and physically fit (Yasht 5, paragraph 2), with golden shoes and a belt, wearing an expensive golden wrinkled mantle (Yasht 5, paragraphs 7, $64 \& 126$ ). She holds a Barsam ${ }^{1}$ in her hand, wears golden earrings and a crown with a hundred diamonds (Yasht 5, paragraphs 127 and 128). She lives among the stars (Yasht 5, paragraph 88), and 4 male horses move her carrousel (Yash 5, paragraphs 11 and 13) which are wind, rain, cloud and hail (Yasht 5, paragraph 120). She must be asked for help to defeat demons and enemies (Yasht 5, paragraphs 23, 26, 46, 50). She has a beautiful face, white arms as big as a horse's shoulders and protruding breasts and as she has a tight belt on her waist, rides on her carrousel and 4 equally sized and colored horses move it (Yasht 5, paragraphs 1113). Anahita wears expensive diamonds, and wears a crown that is decorated with 100 shiny diamonds. She wears shiny shoes and skin (Bahar, 2002: 81). Aredvi sura Anahita meaning powerful clean waters, is the source of all waters on earth. She is the source of fertility and cleans all males' sperms, all females' womb and cleans the milk in mothers' breasts (Yasht 5, paragraph 2). She increases seeds and lands (Bahar, 2002: 81). In middle Persian, Anahit is known with the tile Banug which is seen in Sassanid inscriptions. Banug in Persian has been used among Zoroastrians and

\footnotetext{
${ }^{1}$ Barsam or Barsman, is the cut branches of a tree called Tak and Tai in Pahlavi and Persian, respectively. It seems from Avesta that Barsam must be of vegetation such as pomegranate and tamarisk (tree) and haoma. The branches are usually cut with a tool called Barsamchin. In Farsi cultures, it is written that "Barsam is thin untangled branches and about span of it is cut from the haoma tree and that tree is like tamarisk (tree) and if not haoma, it is tamarisk tree otherwise pomegranate which they cut using Barsamchin while praying and whispering". Sometimes in rituals, metal Barsams made from brass and silver are used instead of plants. Each metal Tai is as long as nine phalanxes and has a diameter of one eight phalanx. In Avesta, the number of Barsams has been mentioned as being from 3 to 35 . Barsams are wrapped in a strap made of palm fiber, such as Koshti and Zoroastrians' belt, this strap is also called Koshti (Ušēdarmāh, 1992, about Barsam).
} 
Muslims; sacrifices were offered to Anahit as a holy goddess, as is described in Yasht 5, paragraphs 15 and 21. For example, in the temple of Persian Banug in Sharifabad of Yazd, cows were sacrificed and this sacrifice was probably offered to Aredvi sura Anahita who was the goddess of water in the Zoroastrian community of Sharifabad (Russell,1987:215). Every year in the day of Eid al-Adha, Muslims in Niyasar of Kashan (whose pre-Islamic beliefs, were transformed in their Islamic practice), beside a fountain located next to a plantain in front of a penthouse that is very sacred to people, sacrifice a $\operatorname{cow}^{2}$ (Javadi, 2007:16). There is a big probability that many holy places located in mountains and near fountains and are called "Dokhtar" or "Bibi", were once dedicated to Anahid. Nowadays, the Zoroastrians of Yazd, call the term daughter as "water of Nahid" (Boyce, 1985: 1006). The goddess Anahita was linked to all society classes. Kings and powerful people constructed beautiful temples for Anahita, such as the temple of Anahita in Bishapour that was a royal temple and was constructed by the order of Sassanid king; common people also had holy buildings for themselves where they praised Anahita and prayed to her; other temples for Anahita known with the name Saghatalaar in the province of Mazandaran included small rooms with wooden ceiling and columns which were also sometimes made with other materials which were located near farmlands where people prayed to Anahita for rain and abundance in their harvests ${ }^{3}$ (adapted form: Javadi, 2007:13).

\section{ANAHITA IN ANCIENT IRAN}

Anahita is the Zoroastrian deity of ancient Iran's mythology. An-ahi-ta means clean and uncontaminated (Gholizadeh, 2013: 93). Her nickname in Avesta is aredvu sura; aredvu is the name of a legendary river and sura means powerful which is an adjective of aredvu and in most cases comes with another adjective which is Anahita meaning clean and in Pahlavi it is Anahid (Afifi, 2004: 634) and in Persian it is Nahid. Aredvu means fertile and blessed (Bahar, 2002:80). The full name of Anahita, Aredvu sura Anahita meaning moist powerful innocent, clearly mentions three functions (Duchesne Giman, 2002: 236). Anahita was a fertile deity and is apparently the same as the Babylonian or Elamite goddess Nane and later Artemis of Greece (Duchesne Giman, 2002: 236). Ardwisur Anahid is the goddess and symbol of water which was always sacred to Iranians. Yasht 5 and Yasne $65^{\text {th }}$ are about her and waters. Her existence with reliance on this very Yasne and Yasht, affects men's birth. Hormoz praises her, Hushang, Gem, Azhdi Hak, Freidun, Garshasb, Afrasiab, Kavoos and others sacrifice for her and ask her for them needs (Yasht 5, paragraphs 17- 47). In the inscriptions of Darius and Xerxes, no mentions of her exists; these two kings considered Ahouramazda as the best master, and the greatest god but did not deny the existence of other gods. During the time of Darius, the existence of other gods was recognized as extra gods beside the allknowing master. Darius calls those gods as "other gods that exist". Xerxes, considered Ahouramazda as the creator of the earth, sky, human and happiness,... "Ahouramazda is the great god, the greatest of gods; who created this earth, happiness, made Xerxes the king, one among many kings, one ruler among many rulers. I, Xerxes, the great king, the king of kings, the king of countries, owning many countries; the king of this vast remote land, son of Darius, the Achaemenid king" (Sharp, 2005:85). But it was from the time of King Artaxerxes the second (359-404 BC) when the name of Anahita goddess was included beside Ahouramazda and Mitra in inscriptions..."The great Xerxes, the king of kings, the king of people, the king on this earth, the son of Darius the king, Darius the son of King Artaxerxes, King Artaxerxes son of Xerxes, King Xerxes son of King Darius, Darius son of the Achaemenid Vishtaspa. He states that, by the will of Ahouramazda and Nahid and Mitra, I built this Apadana Palace. Ahouramazda and Nahid and Mitra protect me from all evil; do not destroy what I have built and no damage be done to it" (Sharp, 2005: 139). It is said that when Artaxerxes the second, related Mitra and Anahita to Ahouramazda, he actually followed the orientation of public masses; in this regard, Ghirshman write: scientists think that the inclusion of Anahita's cult was done by Artaxerxes the second and worship of her statues in Susa, Persepolis, Ecbatana, Babylon, Damascus, Soros and Balkh temples must have been supported by all the nations under one religion whose effects survived for a long time in Minor Asian Nations (Ghirshman, 1970: 232). Merry Buss,

\footnotetext{
${ }^{2}$ For more information look at: Javadi, Sh. (2007), holy places in relation to nature-water, tree and mountain-. Baghenazar Magazine, No. 8, autumn and winter of 2007. From 12 to 22.

${ }^{3}$ For more information look at: Javadi, Sh. (2007), holy places in relation to nature-water, tree and mountain-. Baghenazar Magazine, No. 8, autumn and winter of 2007. From 12 to 22.
} 
considers the start of Anahita worship during Artaxerxes the second's rule as an innovation of Persians. Artaxerxes in an inscription he has in Susa states that the construction of his palace was with the help of Ahouramazda, Anaitis and Mitra and asks them to protect him from enemies. Artaxerxes the second, officially calls Anahita in his inscriptions. Berossos, Kaldeh historian writes in this regard: Artaxerxes the second was the first person that built statues of Aphrodite - Anaitis in Babylon, Susa, Ecbatana, Persepolis, Balkh, Damascus and Sardis and started her praise in that nation; after him, Artaxerxes the third also mentions Anahita beside Ahouramazda and Mitra (Widengren, 1998: 176). In north of Persepolis, there is a large building complex called "Parasteshgah Fertdareh" belonging to the time of Xerxes the second and it is assumed that this complex was one of the king's buildings for Anahita (Boyce, 2007:90).

Parthians like Achaemenian, worshiped Urmozd, Mehr and Anahita as their main deities. The name of Ab-Nahid, is seen for the first time during Parthians. During Parthians, Anahid was very popular. Since the time of Artaxerxes the second, belief in Anahid had become more important than in other deities and the goddess Nahid was also the most important one during Parthians (Ghirshman, 1970: 321). Among Parthians, elements such as water and fire were highly praised. They praised water and rivers and avoided sea voyages because they feared they might contaminate the water and sadden Anahita goddess (Khodadadian, 2000, 256). Worship of Anahita during the Sasanian period was as popular as it was during the Achaemenian period, but during the former, no statues were made for the goddess and instead, in holy buildings, they ignited the holy fire, thus, the cult of idol worshipping which was included by the Artaxerxes the first into the Zoroastrian religion came to its end (Boyce, 2007: 136-137).

Ardashir Babakan, founder of the Sassanian dyNossty, was the guardian of the temple of Anahita in the city of Estakhr, which was considered as a god-blessed honorable position at that time (Avarzamani, 2014: 37) or in Naqsh-e Rustam, Narseh has a stone carving where he introduces himself as a devotee of Anahita. He is depicted in this stone carving as he receives the ring of kingdom from this goddess who is wearing a crown and a complete robe (adapted from, Javadi, Avarzamani, 2008:44). In Taq-e Bostan in Kermanshah, Khosrow Parviz, made the last Sassanian stone carving from the scene of this authority granting where he is receiving the ring of kingdom from Ahouramazda while the goddess of streaming waters and fertility and prosperity who supports this dyNossty, spills water down from a jug in a symbolic manner. During the Sassanid period, holy fires were set in the name of goddess Anahid. For example, they set a fire in Estakhr and offered it to Anahid.

At the time of Bahram II, the great priest "Kartir", introduces himself as the owner of Anahid Artaxerxes and Anahid Banug's fireplace (Yazdani, 2014: 115). During the time of Bahram II, there are two big fireplaces in Estakhr of Pars called Anahid Artaxerxes fireplace and Anahid Banug fireplace whose supervision is under the control of the great priest of that time "Kartir" (Back, 1987:411). Shapur I, constructed a fireplace in Bishapour which is recognized as a fireplace of Anahid because of its unique characteristic. Narseh in his inscription in Paykooli writes: "... Anahid who is called Banug." (Yazdani, 2014: 67).

\section{ANAHITA IN ANCIENT ARMENIA}

According to Jacques De Morgan, there is evidence making us think that Armenians like many IndoEuropeans, started religion with the worship of the nature, therefore these primitive religions, created a form of national monotheism in them, in which many gods and goddesses adapted from Greek and Roman and Iranian myths were included. The old beliefs of Armenians that is religion and worship of deities, is a very diverse and unclear collection. Iranian, Assyrian and Greek gods and goddesses that were very important in terms of cultural-historical relations of those ages and had a great effect on the psychosocial life of Armenians, greatly influenced Armenians' beliefs and also Armenian gods evolved by transforming the gods of those nations (Ivazian, 2012: 77-79). Before the start of the cultural interaction of Iran and Armenia before the time of Achaemenians, the holy goddess of Armenia was called "Nane" who was the third goddess among the Armenian deities. She was the daughter of "Aramazd" who had the greatest position among the Armenian myths. Nane was the sister 
of "Astghik", the Armenian goddess of love, water and sorrow (Baghdarmian, 2001: 53). "Nane" was also called "Nani" and "Nan" which meant mother and grandmother. She was also the goddess of wisdom and virtue, spirit birth and was also called the bride of immortality ${ }^{4}$. According to researchers' belief, "Nane" was of the Sami goddess of Sumer and Akkad (Nurizadeh, 1997: 259) where she was recognized with the name "Nanai". In prehistoric ages, she went to Transoxiana and was praised there; in the temple of "Nanai", the ancient practice of holy prostitution existed (Bahar, 1997:103). Until Armenia was not influenced by Iranian culture, the goddess "Nane" had to be like her Sami origin that means that "Nane" and also other Sami deities such as "Istar", had to be a seductive woman and not a symbol of purity and chastity. But with the increased influence of Anahita in Achaemenid Iran, her name and influence reached beyond the borders of Iran. Nahidism which was rapidly growing during Achaemenian Artaxerxes II and was supported by Iran's high king, made it spread to other parts of the Iranian kingdom; one of these regions was Armenia in which the worship of Anahita became particularly important, therefore, we see the presence of a goddess named "Anahit" in Armenian myths who was known as the increaser of fruits and births and the symbol of mother and best values and the most sacred goddess among the Armenian deities (Baghdarsian, 2001: 53).

With Iran's increased influence in ancient Armenia, we see a rise in the position of this goddess such that the Armenian "Anahit" changes into one of the daughters of "Aramazd" and becomes the sister of two older goddesses "Nane" and "Astghik" and gradually we see that the role of the other two deities fades and gets absorbed into the personality of "Anahit" and their Sami adjectives replace the Iranian adjectives for "Anahit".

"Anahit" was also very important to Armenians; according to Estrabon, Pliny and Plutarch, before Agathange and Khorenatsi, the most popular deity was Anahit. According to a report by "Aganthange" (Armenian historian who was the secretary of King Tiridates III of Armenia and had written the biography of St. Gregory the Illuminator evangelist in Armenia), Anahit loves all mankind, is the great queen, mother of all wisdom and charisma of Armenia (Agathangelos,1976:51). The golden statues of Anahit existed in Artaxata and Artasat and in the border of Taron. According to these evidences it can be said that Anahit is an ancient goddess in Armenia. She is described as the protector and watcher of life (Agathangelos,1976:106). She was also called the golden mother. Golden statues are offered to her. She is the giver of life, lived among her children, she is as the grandmother and deity of harvest and resurrecting waters of rivers and fountains (Russell 1987:257).

Armenians had temples in Akilisene. In Tiladamprada, around Euphrates, there was an Anahita temple as well. According to Aganthange, Anahit had temples in Yastisat (in northwest of Van) (Agathangelos,1976:50). It is said that there existed a statue of Anahita in the border of Anzavatzs near the Black Smith stone (Alishan: 1895:50). Some believe that worship of Anahita in Armenia originated from Zoroastrianism. Although Iranians did not have idols and were not idol worshipper, but according to Herodotus, Artaxerxes (316-404 BC) ordered that Iranians build a statue for Anahita and worship it; because a historian of ancient Greece (Perseus) states that said king, had built statues of Anahita in distant cities of Babylon, Damascus, Hamedan, Sardis and Susa (John Hinls, 1996: 137). Anahita is the opposite of Artemis a Greek myth who was a goddess of virtue and chastity. This claim is properly proven from the words of King Tiridates of Armenia; the great Banug Anahit who is the honor of our nation, is the mother of all wisdom and daughter of the great and brave Aramazd (Abrahamyan, 1970:100-109).

\section{GODDESSES OF FERTILITY}

Arnold Joseph Toynbee says: mother, is the most ancient art subject of mankind, (Toynbee, 1983: 350). Some anthropologists believe that in ancient times, the primitive society was dominated by women and (matrilineal) is a remainder of that time that is matriarchy (Azadegan, 1993: 25). Change in the structure of prehistoric (matriarchic) societies was usually due to the invasion of (patriarchic) desert dwellers. This system is also evident among societies that later joined the written history period. For example among the native people of south-east Australia, until 1869AD, every person

${ }^{4}$ Look at Baghdarmianm 2001: 55 and Ivazian, 2012:95. 
took the ancestry from his/her mother (Noss, 2003:29). Or in Japan, until late $8^{\text {th }}$ century, women governed the states and controlled the politics (Rosenberg, 1998:712). The main concept of matriarchy is not only feminine power, but also the power of woman as a mother. Feminine power is given due to the maternal position of woman in primitive society (Bamberger, 1974:263).

Many beliefs, ceremonies and religious rituals have been formed in relation with the economic needs of humanity such as more product and herds for food, and more children for help with harvesting and strengthening one's family and tribe in times of war. Some of these traditions are common among all ancient civilizations such as grain dancing when planting seeds along with spilling the blood of a sacrificed human or animal and burying the dead body in the ground or offering the first fresh product from the fruits or grain to gods or offering the first child to gods, the symbolic ceremony of the marriages of gods with the goddess of fertility performed by actors (Noss, 2003: 17).

In Greek myths, the first goddess of fertility is Gaia who gives her place to her son and spouse Uranus the male god of the sky. In the next generation of gods, Rhea who is Cronus's wife is tasked with protection of fertility (Rosenberg, 1999:70). After the titans leave godhood to Zeus and his family, Hera becomes the queen of the sky. Ancient Greek mountain dwellers, worshipped Hera and there are many stories about ancient mother-worshippers about him. Whereas, Zeus was the god of the northern invading tribes (who were father worshippers) and in order to establish his place in the defeated country, he married Hera (Noss, 2003: 81). Among the children of Zeus, Aphrodite, Artemis, Athena and Eileithyia are somehow related to fertility; Aphrodite was worshipped in Phoenicia and Assyria in the form of a pyramid with blazing torches and in Egypt she was identical to Hathor. The cult of Aphrodite was brought into Greece by Phoenicians which with the title Urania, was the symbol of ideal love (Fazaeli, 2004:71). More than any other deity, Aphrodite has been praised by artists and as a model for feminine beautify, inspired esthetes and caused the creation of many art works. Artemis was the lady of the wild and the hunting mistress of gods and caretaker of infants (Hamilton, 2004: 36). Several east-origin goddesses were mixed together to create the myth of Artemis; the Persian Anahita, Turkish Banis, Cretan Dokerton and ... she was asked for the fertility of herds and women, but Artemis herself, was proud of her eternal virginity and preferred hunting and war over marriage (Fazaeli, 2004:40).

In Roman mythology, Ceres, was the goddess of farming, vegetation and the cultivation of crops and plants and was considered as the goddess of fertility and maternal relations. There were different forms of cults for worshipping her.

She was originally the central deity in Rome's so-called plebeian or Aventine Triad, then was paired with her daughter Proserpina in what Romans described as "Greek rites of agriculture and vegetation". She played an important role in the marriages and funerals of Romans. Seven days of the month Avril belonged to her in in which the popular festival of Cerealia was held. In May, and also at the Ambarvalia festival at harvest-time, she was honored. Her tasks and duties and also her rites of worship, are similar to her Greek counterpart Demeter and this Greek goddess has commonalities in many mythological aspects with Ceres (Perowne, 2002: 47).

Hetaira $^{5}$ which was initially a form of a rite of worship of mythological gods, was common in Greece, Armenia, Assyria and Babylon. Such that Istar the goddess of love, war, dawn and dusk was considered as being the same as the planet Venus. In this position, in her shrine, holy prostitution was part of Istar's cult and when she visited the earth, prostitutes and whores accompanied her. Istar was

${ }^{5}$ Hetaira: Traditionally, historians of ancient Greece have distinguished between hetairai and pornai, another class of Greek prostitute. In contrast to pornai, who provided sex for a large number of clients in brothels or on the street, hetairai were thought to have had only a few men as clients at any one time, to have had long-term relationships with them, and to have provided companionship and intellectual stimulation as well as sex. ( Kurke, Leslie (1997). "Inventing the "Hetaira": Sex, Politics, and Discursive Conflict in Archaic Greece". Classical Antiquity 16 (1): 107-108.) 
also considered the prostitute of gods. The special ceremony for this mythological belief, was held in Armenia in the temple of Anahita; but there is no evidence to support this subject and Christian authors have not mentioned anything in this regard. Ceremonies related to Hetaira in the temples of the fertility goddess in Iran, belong to the period before the coming of Aryans which remain from the time of matriarchy in Iran before Aryans (Nurizade, 1997: 267-268).

The idea of prostitution for Anahita may be due to the mixture of Iranian, Babylonian and Greek beliefs and cultures whose gods were very similar to the point that a group of people consider Anahita as being the same as the Sami and Greek goddesses (Amini Lari, Mahmudi, 2016:62). Therefore, regarding the Iranian goddess, the protector of pure and clean waters and fertility, there was no rite mixed with obscenity and the rites related to Anahita were mixed with purity, cleanness and blessing; the goddess of waters had always been a pure mistress away from seduction and obscenity and never like the Greek or Sami goddesses; the mistresses who served in these temples had a purity pledge.

\section{CONCLUSION}

In ancient times, religions had always been influenced by the religions of other nations and also influenced them. Armenians' beliefs in ancient times, were very much influenced by the Iranians which is evident after the change of Armenians' religion to Christianity, such that the ancient beliefs transformed and survived into the new religion. By comparing Anahita in Iran and Armenia, it can be concluded that "Nane" in Armenia which originated from Sami goddesses and was influenced by Iranians' beliefs particularly during the Achaemenian period when orientation towards "Nahid" had increased amongst Iranian kings, changed her identity from a Sami deity and turned into the Iranian Anahita and her goddess functions became very similar to the Iranian goddess;

\section{REFERENCES}

Amini Lari, L., Mahmudi, Kh. (2010). Nahid is holy or lust? Research in Persian Language \& Literature journal, No. 7, autumn 2010, from 51 to 64.

Ushidari, J. (1992), Zoroastrianism Encyclopedia, descriptive dictionary of Zoroastrianism. Tehran. Markaz publications.

Ivazian, M. (2012). Commonalites in myths and beliefs in Iranian and Armenian references. Tehran. Institute for Humanities and Cultural Studies.

Azadegan, J. (1993), primitive religions. Tehran. Miras-e-melal publications

Avarzamani, F. (2014). Sassanid art. Tehran, Publishing Cultural Institute of Pazine.

Baghdasarian, E. (2001), History of the Armenian church. Tehran: Author.

Boyce, M. (2006). A history of Zoroastrianism. Translated by Homayun Sanatizadeh, vol. 1. Tehran, Tus publications

Boyce, M. (2007). Zoroastrians, their religious beliefs and practices. Translated by Asgar Bahrami. Tehran, Ghofnoos publications.

Bahar, M (1997). From myth to history. Tehran. Cheshme publications.

Bahar. M (2002). A research on Iran's myths. Vol. 4. Tehran, Agah publications.

Perowne, S. (2002). Roman mythology. Translated by Bajlan Farakhi. Tehran. Asatir publications.

Pourdavud, E. (1960), Yashtha. Vols 1 and 2, Tehran. Farahvar publications.

Toynbee, A. (1983). Mankind and mother earth: a marrative history of the world. Translated by Yaghoub Azhand, Tehran. Molavi publications.

Javadi, Sh. (2007). Holy places related to nature-water, tree and mountain-. Baghenazar magazine, No. 8, autumn and winter of 2007. From 12 to 22.

Javadi, Sho. Avarzamani, F. (2009) Sassanid stone carvings. Tehran, Balkh publications.

Khodadadian, A. (2000). Parthians, Vol. 1. Tehran. Beh-did publications.

Duchesne, G. J. (2002). Religion of anicent Iran. Translated by ROya Monjem. Vol. 1. Tehran. Elm publications.

Rosenberg, D. (1999). World my theology: an anthology of the great myths and epics. Translated by Abdolhossein Sharifian. Tehran. Asatir publications.

Zarrinkoob. A. (2015). History of Iranians: pre-Islamic history. Tehran. Amir-Kabir publications.

Sharp, N. (2005). The imscriptions in old persian cuneriform of the Achaemenian emperors. Tehran. Publishing Cultural Institute of Pazine. 
Shahbazi. A. (1978). Illustrated guide of Naghsh-e-rostam. Shiraz. Research Institute of Persepolis. Afifi, R. (2004). Iran's myths and culture. Tehran. Tus publications.

Fazaeli, S. (2004), culture of wonders. Tehran. Mirase Farhangi publications.

Gholizade, Kh. (2014) culture of Iranian myths. Tehran. Parseh publications.

Ghirshman. R. (1970). Iran Des origines A L'Islam [Iran, since the beginning of Islam]. Translated by Mohammad Moin. Vol. 3. Tehran. Bongahe Tarjomeh Va Nosshre Ketab.

Noss, J.B., (2003). Man's religions. Translated by Ali Asghar Hekmat. Tehran. Elmi-Farhangi publications.

Nurizadeh. A. (1997). History and culture of Armenia since the beginning until now. Tehran. Cheshmeh publicaions.

Widengren. G. (1998). Lesreligions de L'Iran [Iranian religions]. Translated by Manuchehr Farhang $\mathrm{PhD}$. Tehran, Agahan Eedeh publications.

Hamilton. E (2004). Mythology, Timeless tales of Gods and Heroes. Translated by Abdolhossein Sharifian. Tehran. Asatir publications.

Hinnells, J. (2006). Persian mythology. Translated by Zhale Amouzgar and Ahmad Tafzili. Vol 6. Tehran. Cheshmeh publications.

Yazdani. K. (2014). Sassanid inscriptions guide. Shiraz. Takhte-Jamshid Publications.

Abrahamyan, A.G. (1979). Matenagrutcyun. trans And ed Anania širakacci. Erevan.

Agathangelos, R.W. Thomson. 1976. History of the Armenians. Allbany: state university of New York

Alishan, A. (1895). Ancient fate of the Armenian. Venice.

Back,M.(1978) Die Sassanidishen Staatsinschriften,Acta Iranica. Vol 18. Leiden .

Bamberger, Joan. (1974) The Myth of Matriarchy Stamford University press .

Boyce, Mary. (1985). "Anāhid". Encyclopaedia. Iranica Vol 1. London and Boston.

Russell, James. (1987). Zoroastrianism in Armenia. Harvard university. 